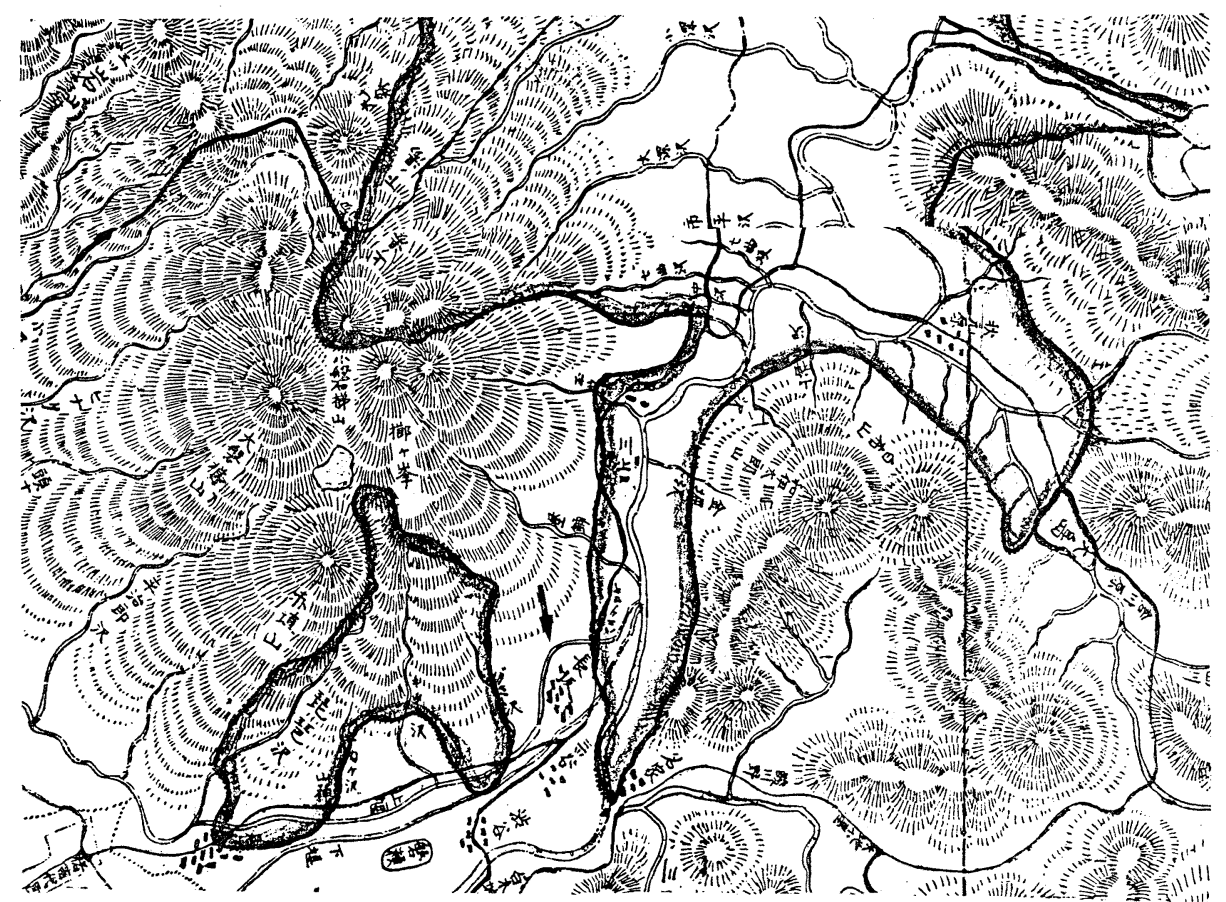

この図は福島県立図書館で得た磐梯山噴火埋没図（製作者不明）の1部分を示してある。噴火後 の岩屑流・泥流の範囲を明瞭に示しており，長坂部落（矢印）の主要部は土石流から免れている ことが判る。

てきて多くの犠牲者を出したことが分かった。

5) まとめ

磐梯山噴火は岩属流発生という特異な噴火形態 を示し, 火山学上からも災害軽減のためにも貴重
な出来事であった。このときの記録を出来るだけ 収集して噴火経過と災害発生の要因を理解するこ とは将来のために重要である。まだ収集と整理は 完全ではないので，今後もそれを続けたい。

群馬県中里村産恐竜足跡の分類学的な再検討

松川 正樹* 小畠 郁生** Martin G. LOCKLEY***

Taxonomical Re-examination of Dinosaur Footprints from the Cretaceous Sebayashi Formation, Japan

Masaki MatsukawA* Ikuwo OBAtA** Martin G. LockLEY***

I. はじめに

足跡化石の研究の主な問題の一つは, 不明瞭な
輸郭の足跡の認定とその分類である。教科書に載 せられている保存のよい輸郭の明膫な足跡は，無 数にある足跡化石の記録の中のごく僅かの例に過

* 愛媛大学理学部地球科学教室 Department of Earth Sciences, Faculty of Science, Ehime University

** 国立科学博物館地学研究部 Department of Geology, National Science Museum

*** Department of Geology, University of Colorado at Denver 
ぎない。足跡化石はそれを残した動物の行動の記 録を示しているので，不明膫な輪郭の足跡化石の 認定やその分類ができれば，過去の動物の行動， 生活様式，生息域なぞについての情報量が増え る。

不明瞭な輪郭の足跡化石の認定は，先の足跡の 特徴とその不明膫さの原因を考察することから始 まる。現時点では，不明膫な輪郭の足跡を扱った 研究が少ないので, 不明瞭な輪郭の足跡の産状や 特徵の例を多く集め，その原因を考察することが 行われている。

群馬県中里村瀬林の白亜系の漣岩と呼ばれる崖 にみられる恐竜の足跡は不明膫な輪郭をもつもの で, 不明瞭な輪郭の特徵, その成因, 分類につい ての記載と考察を行った研究例のひとつである (MATSUKAWA and Obata 1985, 1989 ; Lo. CKLEy, MATSUKAWA and OBATA 1989)。 特に, 分類に関しては, 韓国産の足跡の中に瀬林 産と同じ特徴をむつものがあることを見いだし て, Iguanodon 類に属すると結論らけた（松 川・梁・小畠 1987)。しかし，1987年に来日し た著者の一人の LOCKLEY は, Iguanodon 類と した足跡とその周囲にある MATSUKAWA and OBATA（1985）が解析できなかった多くの凹み との関連性から，それらが二足歩行の肉食恐童 Theropod のものの可能性が有ることを指摘し た。そこで，この問題点を解決するために瀬林産 の足跡の分類学的な再検討を実施した。

また，今回の研究では，瀬林産の足跡のあるも のに認められる放射状と同心円状の割れ目の発達 する足跡と同様の特徴をもつ恐竜の足跡がコロラ ド州の白亜系のダコタ層群でも発見されたので, 両者の比較検討も行った。放射状と同心円状の割 れ目の成因を考察した。

本研究を進めるに当たり, 助成金を頂いた東京 地学協会, 現地での有意義な討論を頂いたコロラ ド大の Mark JONES 氏, 現地での便宜を計って 頂いた中里村教育委員会の小林信夫事務局長, 中 里村恐竜センターの高橋 功氏に厚く御礼申乙上 げる。なお本論文は, 内容の議論を 3 者で行い, 松川と小畠が日本語原稿案を作成した。従って, 日本語文の責任は，松川と小畠にある。

\section{II. 恐竜足跡の特徵と分類の再検討}

群馬県中里村瀬林の漣岩にある恐竜足跡には, Aグループと Bグループの二つの歩行跡が認めら れる。B グループの足跡は, 崖斜面の下部から上 部にかけて認められ，多くの凹みからなる。その ため，比較的保存よく外形の特徴を表しているも のを基にして，その前後にある同じ特徴をもつ凹 みを探し，グルーピングした後に一連の足跡であ ることを認定する。この作業により，一連の歩行 跡を認定し, 仮に animal-Ba と呼称した（MATSUKAWA and OBATA 1985)。今回の調査で は, 漣岩の 崖斜面の 比較的上部にある 4,6 , 38，8-3，9，12の番号づけがされた一連の凹 み（松川・小畠 1986）が同じ特徴をもち，その 深さがいずれも $4 \mathrm{~cm}$ で，漣岩の下部にあるいず れの凹みよりも深いことを確認した。これは，上 部にある 4 から12の凹みが含水量の同じ堆積物に 同一の加重が掛かったことによりできたことを表 し，同一の動物（恐竜）により作られたからだと 解釈される。凹みは, 外形や大きさの特徵に加え て, その梁さの特徴からみても足跡で, その連続 性から一連の歩行跡であることが追認できた。な お，崖斜面の下部の多くの凹みや上部にある多く の小さな凹みと, これら 4 から12の凹みとの連続 性や関連については未解決である。

animal-Ba の足跡は，(1) 二足歩行, (2) 後 足が三本指で, それらは短く,太い, (3) 中央の 指 (Digit III) がやや内側に向く, (4) 後足の長 さが $25 \mathrm{~cm}$ 程度, ストライドが $130 \mathrm{~cm}$ ほどある 特徵をもつ。これは, animal-Ba が Iguanodontidae (HAUBOLD 1971) に属することを示す。 この特徴に加えて, 中央の指 (Digit III) の先端 が truncate する特徴がある。この特徴は, HAUBOLD (1971) や LEONARDI (1984) が Iguanodontidae に属するとしてあげたものには知ら れていなかった。この特徴をもつ足跡が韓国の慶 尚層群産の足跡にも認められ, それは animalKA と呼称された。そして, 両者の類縁性の高 いことが, 中央の指の先端が truncate する特徴 のほか, 歩角 (pace angulation), 歩行跡の幅 （trackuray breadth）の測定值の類似性から述べ 
られている（松川・梁・小畠 1987）。今回の検 討結果でも，中央の指 (Digit III) の先端が truncate 寸る特徴が韓国のそれに比較できること， 足跡の大きさとステップの長さの異なることを追 認した。これは, 日韓両国産の恐竜足跡の類似性 の解釈（松川・梁・小畠 1987）を支持する。

\section{III. 放射状と同心円状の割れ目で特徴づけら れる足跡}

群馬県中里村瀬林の 漣岩にある A グループ の 足跡には放射状と同心円状の割れ目が発達する (MATSUKAWA and OBATA 1985)。これま

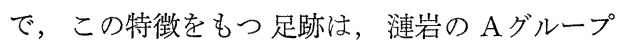
以外知られていなかった。最近, 著者の一人の LOCKLEY はコロラド州の白帚系ダコタ層から放 射状と同心円状の割れ目が発達する恐竜足跡を多 く発見した。

ダコタ層産のものは, $2 \mathrm{~m} \times 4 \mathrm{~m}$ の石板上に鳥 の足跡と恐竜足跡の natural (original) cast と 恐竜足跡の underprint (natural print の印され た層の下の層に印された “ghost print”）の natural cast が認められる。鳥の足跡は明瞭な輪郭 をもつものと不明瞭なそれで特徴づけられる。一 方, 恐竟の足跡は, (1) 輪郭が不明膫で, 最も踏 みつけられた点を中心に盛り上がっているもの，

（2）それに放射状の割れ目が発達するもの，(3)

同心円状の割れ目が発達するもの，(4) 盛り上が りもなく放射状の割れ目のみが発達するむのから なる。明瞭な鳥の足跡は, 足跡の成立の時に堆積 物が適当な湿り気を持っていたことを示し，水面 が堆積物のすれすれにあったと推定される。一 方, 不明瞭な足跡は, 最も踏みつけられた点を中 心になだらかな斜面を持っていたり，放射状の割 れ目が発達したりする。これは，足を踏み込んだ 時に堆積物の表面に圧力が働き, 足を取り除いた 時に最も圧力の掛かった低い点に向かって堆積物 が戻ったことを示す。堆積物の含水量の不適量さ と underprint であることが原因すると考えられ る。このように狭い範囲の中に明瞭な輪郭と不明 瞭な足跡が存在するということは, 足跡の成立時 に場所による堆積物の水の飽和量の僅かの相違が 有ったことに原因することを表していると解䣋さ
れる。これは, 瀬林の漣岩にあるAグループの足 跡に発達する放射状と同心円状の割れ目が足跡の 成立時に堆積物の含水量の不適量さに基づいて形 成されたといら解釈（松川・小畠 1986）と同様 である。漣岩では足跡の深さや割れ目の発達の程 度が非常に近接した地域で異っているという特異 性がある。

\section{IV. 結 論}

（1）群馬県中里村瀬林の漣岩にある恐竜の足跡 の主たるものが韓国産のそれに比較できることを 追認した。

（2）瀬林産の足跡の中に認められる放射状と同 心円状の割れ目の発達する足跡と同様の特徵をも つコロラド州の白亜系のダコタ層群の恐竜足跡と 比較検討を行った。放射状と同心円状の割れ目 は, 足跡が印されるときの堆積物の含水量の不適 量さに基づくことを推定した。

（3）近接する地域に輪郭の明瞭な足跡と不明瞭 なそれが存在するのは，足跡の成立時の場所によ る堆積物の水の飽和量の僅かの相違が原因すると 解釈される。

\section{文献}

HAubold, H. (1971) : Ichnia Amphibiorum et Reptiliorum fossilium. Handbuch der Paläoherpetologie, 18, 123p.

LEONARDI, G. (1984): Glossary and manual of Tetrapod footprint palaeoichnology. Dep. Nacion. da Prod. Mineral, $75 \mathrm{p}, 20 \mathrm{pls}$.

LOCKLEY, M., MatSUKAWA, M. and OBA TA, I. (1989): Dinosaur tracks and radial cracks : unusual footprint features. Bull. Nat.Sci, Mus., C, 15, (in press).

MatsukaWA, M. and Obata, I. (1985): Dinosaur footprints and other indentations in the Cretaceous Sebayashi Formation, Japan. Ibid, 11, 9-36.

and (1989): Interpretation of dinosaur footprints from the Lower Cretaceous Sebayashi Formation, Japan. 409-412 in Dinosaur Tracks and Traces, Gillette, D. D. and Lockley, M. G. (eds). Cambidge Univ., Press 454p.

松川正樹 - 小畠郁生 (1986)：下部白巠系瀬 
林層の恐竜足跡，月刊地球，8，149-157. ——・梁承榮・小畠郁生 (1987)：日本産と
韓国産の恐童足跡の比較研究. 地学雑誌, 96, 54-56.

トレンチ掘削調查による中央構造線活断層系岡村断層

の活動時期と変位量の解明

岡田 篤正* 中田 高** 堤 浩 之**

\title{
Analysis of Fault Activity and Amount of Displacement of the Okamura Fault, Median Tectonic Line Active Fault System, by the Trench Excavation Survey
}

\begin{abstract}
Atsumasa OKADA*, Takashi NAKATA** and Hiroyuki Tsutsumi**
\end{abstract}

\section{I.はじめに}

西南日本を内帯と外帯に区分し，地質構造の上 で大境界をなす中央構造線は, 第四紀においても 右横ずれの卓越した運動を繰り返している活断層 である。このうち，とくに活動的なのは紀伊半島 中部以西であるが，とりわけ四国北縁部にみられ る石鎚断層崖麓の地域で顕著である。ここでは, 中央構造線および並走する活断層系に沿って明膫 で模式的な断層変位地形を見ることができ，それ らの変位速度は日本の内陸活断層では最大級であ る(岡田 $1973 \mathrm{a}, \quad \mathrm{b}$ )。中央構造線活断層系の 活動の履歴や断層運動の規模を解明することは, 単に地震の長期的な予知に役立つのみならず, 地 形発達史研究にとっても重要な基礎データとなる と思われる。

これまで日本各地で行われたトレンチ掘削調查 では，断層運動の時期の解明に重点がおかれてき たが, 断層運動に伴う変位量の解明に積極的に取 り組んだ例は少なかったように思われる。そこ で, 今回の調查では断層運動に伴う変位量の解明 にとくに重点を拉いたトレンチ掘削調查を行うこ ととした。

\section{II. 調查の経緯と調査地付近の地形・地質}

調查地は愛媛県西条市飯岡字半田の四国縦貫道 西条インターチェンジ進入路建設予定地である。
この地点は狭義の中央構造線の北側 $1.5 \mathrm{~km}$ であ り，更新世中～後期に形成された段丘面を開析す る谷 (=小扇状地) の上に位置している。この付 近では南側を走る狭義の中央構造線が西方へ行く に従って活動的でなくなり，代わりに北側を並走 する岡村断層が活動的になる。したがって, 岡村 断層は中央構造線活断層系の運動や活動履歷を代 表しているので, この調査汁有意義である。

ここでは1984年に京都大学防災研究所によるト レンチ掘削調查が行われている（安藤ほか $1984 ，$ 岡田 1984, 京都大学防災研究所 1985, 岡田ほ か 1986，1988)。これらによれば，耕作土の直 下までのすべての地層を変位させる断層が観察さ れた。地層中に含まれていた腐植や木片の ${ }^{14} \mathrm{C}$ 年 代測定結果や地層に狭在していた考古遺物の時代 鑑定結果などにより, 最新の大地震は有史直前の 4〜6世紀に起こったと推定された。それ以前に も何回かの大地震の発生が推測され，約 1,000 年 毎に大地震が発生してきたという, この断層の活 動間隔が求められた。断層運動による右横ずれ変 位速度は, 少なくとも $5 \mathrm{~m} / 10^{3}$ 年と求められた。 観察された地質断面では, 地形から予想される垂 直変位の向きとは逆に北側が相対的に隆起してい たが，これは扇状地中心線に沿う地形的な高まり 部分が，断層運動に伴って移動してきたことによ る, みかけ上の現象と解釈されている。

京大防災研究所と共同して行った冬 (1988年 3

* 愛知県立大学文学部地学研究室 Faculty of Literature, Aichi Pref. Univ.

**広島大学文学部地理学教室 Department of Geography, Hiroshima Univ. 